\title{
In vitro Evaluation of Fungicides, Botanicles and Bio-Agents against Alternaria alternata Causal Agent of Fruit Rot of Brinjal
}

\author{
Sanjeev P. Jakatimath ${ }^{1 *}$, R.K. Mesta ${ }^{1}$, I.B. Biradar ${ }^{2}$, Sadanand K. Mushrif ${ }^{3}$ \\ and P.S. Ajjappalavar ${ }^{4}$ \\ ${ }^{1}$ Department of Plant Pathology (University of Horticultural Sciences), \\ Bagalkot-587104, Karnataka, India \\ ${ }^{2}$ Department of Agronomy (University of Horticultural Sciences), Arabavi, Karnataka, India \\ ${ }^{3}$ Department of Plant Pathology (University of Horticultural Sciences) Kolar-563101, \\ Karnataka, India \\ ${ }^{4}$ Horticultural Reasearch Station (University of Horticultural Sciences) Devihosur, \\ Haveri, Karnataka, India \\ *Corresponding author: Jakatimathsanjeev7@gmail.com
}

\begin{tabular}{|c|c|}
\hline & A B S T R A C T \\
\hline $\begin{array}{l}\text { Ke y w o r d s } \\
\text { Alternaria alternate, } \\
\text { Evaluation of } \\
\text { Fungicides, } \\
\text { Antagonism. }\end{array}$ & \multirow{3}{*}{$\begin{array}{l}\text { Fruit rot of brinjal caused by Alternaria alternata is an important disease of } \\
\text { eggplant inflicting heavy losses. The present investigation was carried out to } \\
\text { test the efficacy of fungicides, botanicals and bio-agents in vitro. Among } \\
\text { fungicides tested, tebuconazole, difenconazole showed } 100 \text { per cent mycelial } \\
\text { inhibition of Alternaria alternata. The results of botanicles tested in vitro } \\
\text { revealed that onion and garlic bulb extract showed highest inhibition of } \\
\text { mycelial growth both @ } 5 \text { and } 10 \text { per cent concentration. The results of dual } \\
\text { culture technique revealed that fungal bio agents were better than bacterial bio- } \\
\text { agents in inhibiting the growth of Alternaria alternata. All the strains of } \\
\text { Trichoderma harzianum were found antagonistic to A. alternata, however } \\
\text { stronger antagonism was noticed in case of T. harzianum- } 21 \text {. }\end{array}$} \\
\hline Article Info & \\
\hline $\begin{array}{l}\text { Accepted: } \\
\text { 04 April } 2017 \\
\text { Available Online: } \\
\text { 10 May } 2017\end{array}$ & \\
\hline
\end{tabular}

\section{Introduction}

Brinjal or egg plant (Solanum melongena L.) is an important vegetable crop belongs to the family solanaceae. It's one of the most common, popular and principal vegetable crops grown in the tropical and sub tropical areas. It's a highly productive and usually finds its place as the poor man's crop. This crop is extensively grown in India, Pakistan, Bangladesh, China and Philippines.
South Asia accounts for almost 50 per cent of world brinjal area under cultivation (Harish $e t$ al., 2011). In India, brinjal is mainly grown in the states like West Bengal, Orissa, Bihar, Gujarat, Maharastra, Andhra Pradesh, Karnataka etc. with an area of 7.22 lakh hectare with a production of 135.58 metric tonnes and productivity of 19.10 tonnes per ha (Anon., 2014). It contributes about 12.47 
per cent of the total production of vegetables in India. In Karnataka, brinjal is cultivated over an area of 15,800 ha with a production of 4002.50 tonnes (Anon., 2014). The crop suffers from fruit rot during harvesting stage caused by Alternaria alternata which account for huge losses to farmer. In India, the disease Alternaria fruit rot of brinjal was first reported from IARI, New Delhi. This disease is severe and apperars regularly, causing heavy losses in fruit yield. When the environmental conditions are favourable the fruit rot incidence can be up to $50 \%$ and this can result serious economic losses, (Smith and Black, 1990).The fruit infection takes place during fruit formation just some days prior to the harvest of the crop. This infection becomes severe at the time of harvesting to marketing. Some farmers are found using available fungicides indiscriminately and unscientifically in Bagalkot district of Karnataka in brinjal fruit rot management. Therefore, the experiment on efficacy of fungicides, botanicals and bio-agents for the management of fruit rot brinjal was taken under study.

\section{Materials and Methods}

The efficacy of 5 systemic fungicides at the concentration of $0.25,0.5,0.75$ and 1 per cent and three non-systemic fungicides at the concentration of $0.25,0.5,0.75$ and 1 per cent was determined. The evaluation of fungicides was based on the active ingredient consideration. Required quantity of individual fungicide was added separately into sterilized molten PDA so as to get the desired concentration of the fungicides. Later, $20 \mathrm{ml}$ of the poisoned media was poured into sterilized Petri plates. Mycelium discs of five $\mathrm{mm}$ diameter from seven days old culture of the fungus were cut out by sterile cork borer and one such disc was placed at the centre of each plate. PDA without any fungicide served as control. Three replications were maintained for each concentration. Plates were incubated at room temperature for seven days and radial growth was measured when fungus attained maximum growth in control plates. The efficacy of the fungicides was expressed as per cent inhibition of mycelial growth over control which was calculated by using the formula of Vincent (1927). To evaluate the antifungal activity of botanicals fresh samples were washed in tap water and finally washed thrice using sterilized distilled water. They were crushed in a sterilized pestle and mortar by adding little quantity of alcohol $(1: 1 \mathrm{w} / \mathrm{v})$ just enough to moisten the samples so that it was easy to crush. The extracts were strained through the two layers of muslin cloth. Finally, filtrates thus obtained from the leaves were used as stock solution (Begum and Bhuiyan, 2006). To study the antifungal mechanism of plant extracts, poisoned food technique was followed as suggested by Nene and Thapliyal (1982). For this, 5 and $10 \mathrm{ml}$ of stock solutions were mixed with 95 and $90 \mathrm{ml}$ of sterilized molten potato dextrose agar medium respectively so as to get 5 and 10 per cent concentration. The medium was shaken thoroughly for uniform mixing of plant extract.

About $20 \mathrm{ml}$ of medium was poured into each of the $90 \mathrm{~mm}$ sterilized petri plates. Each plate was seeded with $5 \mathrm{~mm}$ mycelial discs aseptically taken from the periphery of 7 days old culture and incubated at $27 \pm 1^{\circ} \mathrm{C}$ till the growth of the colony reaches maximum in control plate. Three replications were maintained for each treatment. Suitable control plates were maintained. Mean colony diameter in each case was recorded. The efficacy of the botanicals was expressed as per cent inhibition of mycelial growth over control which was calculated by using the formula as given by Vincent (1927).

Bio-agents were evaluated for their efficacy through dual culture technique. Twenty $\mathrm{ml}$ of 
sterilized and cooled potato dextrose agar medium was poured into sterilized Petri plates. Fungal antagonists were evaluated by inoculating a pathogen at one side of the Petri plate and the antagonist at exactly opposite side of the same plate by leaving about $4 \mathrm{~cm}$ gaps. For this, actively growing cultures were used. In case of bacterial antagonist evaluation, two mycelial discs of pathogen were inoculated at the periphery of the Petri plate and bacterial antagonist was streaked in the centre of the same plate. After required period of incubation i.e., when the growth in control plate recorded $90 \mathrm{~mm}$ in diameter, the radial growth of the pathogens was measured. Per cent inhibition over control was worked out according to the equation given by Vincent (1927). The different antagonistic organisms used against brinjal fruit rot pathogens includes, Trichoderma harzianum strains T-21, T-28, T-29, T-72, T-p, Pseudomonas fluorescens and Bacillus subtilis maintained at biocontrol unit of UHS Bagalkot.

Per cent inhibition (I) $=\frac{\mathrm{C}-\mathrm{T}}{\mathrm{C}} \times 100$

Where,

$\mathrm{I}=$ Per cent inhibition

$\mathrm{C}=$ Growth in control

$\mathrm{T}=$ Growth in treatment

\section{Results and Discussion}

Five systemic and three non-systemic fungicides were tested at four concentrations in the laboratory for their efficacy against Alternaria alternata causing fruit rot of brinjal as described in 'Material and Methods'. The results are presented here under.

Table 1 revealed that there is significant difference between the fungicides tested. The efficacy was found increased in all the fungicides when concentration increased. Difenconazole and tebuconazole recorded
100.00 per cent inhibition at all the concentration tested and hence recorded mean inhibition of 100.00 per cent propiconazole (91.25) and carbendazim (85.41) were the next best fungicides when mean per cent inhibition was considered.With reference to interaction between fungicides and concentrations, difenconazole and hexaconazole recorded 100.00 per cent inhibition at $0.25 \%$ concentration while propiconazole at $0.75 \%$ and 1.00 per cent recorded 100.00 per cent inhibition. Propiconazole at $0.5 \%$ (93.21), carbendazim at $1.00 \%$ (93.00 per cent) and hexaconazole at $1.00 \%$ (92.33 per cent) were next in order and on par with each other. The results are depicted in the Fig.1

The Table 2 showed that there is a significant difference between the treatments with respect to per cent inhibition of radial growth.

At 5 per cent concentration garlic bulb extract and onion bulb extract both $100 \%$ recorded maximum inhibition followed by kokum fruit extract $(50.36 \%)$, clerodendron leaf extract $(50.36 \%)$ and lantana leaf extract and turmeric rhizome extract both $(48.14 \%)$. The least inhibition was recorded in neem seed kernel extract (38.14\%). The results are depicted in the Fig 2.

At 10 per cent concentration highest inhibition was recorded in garlic and onion bulb extract $(100 \%)$ followed by turmeric rhizome extract $(61.62 \%)$ which is on par with clerodendron extract $(61.10 \%)$. The least inhibition of 50.73 per cent was observed in drumstick leaf extract followed by kokum fruit extract $(52.59 \%)$.

The antagonistic activity of five strains of Trichoderma harzianum, Bacillus subtilis and Pseudomonas fluorescens were assayed against $A$. alternata by dual plate technique as explained in material and methods. The 
results revealed that, among all the biocontrol agents tested, Trichoderma harzianum-72 (87.00\%) was most effective in inhibiting the mycelial growth of Alternaria alternata than all other treatments. $T$ harzianum-21 (83.00\%), T. harzianum-29 (81.32\%) and T. harzianum-28 (80.00\%) were next best and the least mycelial inhibition was observed incase B. subtilis $(7.66 \%)$ and $P$. fluorescens $(12.00 \%)$ Table 3 and results are depicted in Fig 3.

In present investigation, all the fungicides tested showed better inhibition of the mycelial growth and sporulation of Alternaria alternata. Difenconazole and tebuconazole showed maximum inhibition followed by carbendazim and propiconazole. Difenconazole and tebuconazole recorded 100 per cent inhibition at 0.50 per cent concentration. No other fungicide recorded 100 per cent inhibition at the same concentration tested. The highest inhibition was recorded by difenconazole and tebuconazole at all concentrations which were significantly superior to all other fungicides tested at the same concentration. Among all, least inhibition of mycelial growth at all concentrations was observed in captaf which was least effective in inhibiting mycelial growth and sporulation of Alternaria alternata. This variation in fungus sensitivity is to be expected with the more specific benzimidazole and oxathiin compounds and is well documented (Bollen \& Fuchs 1970; Snel et al., 1970; Edgington et al., 1970), Triazole are known to inhibit the sterol biosynthesis pathaway in (Nine and Thapliyal ). Simimilar observations were reported by Kalra and Sohi (1984) and Singh and Shukla (1984). Mathur and Shekhawat (1986) who reported that Blitox-50 and Dithane M-45 were found most effective against Alternaria solani. Kamble et al., (2000) studied efficacy of six fungicides against tomato and brinjal leaf spot caused by Alternaria alternata and reported that mancozeb was found highly effective in inhibiting the mycelial growth followed by copper oxychloride and iprodione at 1000, 2000 and $3000 \mathrm{ppm}$. But in contrary to our investigation blitox was second least effective treatment recorded mean inhibition of $(68 \%)$. Ghosh et al., (2002) observed that dithane M$45(0.25 \%)$ and bavistin $(0.1 \%)$ were most effective against mycelial growth and sporulation of Alternaria alternata in vitro.

To find out possibilities of replacing fungicides with other eco-friendly products for management of disease, plant extracts of garlic, lantana, neem, onion, kokum, turmeric, drumstick and clerodendron were tested in vitro against the mycelial growth and sporulation of Alternaria alternata. In present investigation garlic and onion bulb extract were found most effective against mycelial growth and sporulation of Alternaria alternata followed by clerodendron leaf extract, kokum fruit extract, lantana leaf extract, turmeric rhizome extract and drumstick leaf extract at 5 and 10 per cent concentration. Singh and Majumdar (2001) reported that extract of Allium sativum showed lowest root rot disease severity caused by Alternaria alternata followed by Ocimum sanctum and Zingiber officinale. Chaudhary et al., (2003) observed that bulb extract of Allium sativum was highly effective in inhibiting the growth of Alternaria alternata causing early blight of potato. Prasad and Naik (2003) observed that extracts of garlic and neem were most effective against leaf blight of tomato caused by Alternaria solani. Panchal and Patil (2009) reported that garlic clove extract $(10 \%)$ was proved to be best in inhibiting mycelial growth and sporulation of Alternaria alternata incitant of fruit rot of tomato followed by turmeric and neem leaf extract on the contrary in present investigation neem was recorded mean inhibition of (56.66). To circumvent pollution hazards due to un- 
judicious use of agrochemicals and also to avoid development of resistance in pathogenic fungi against commonly used fungicides, use of plant extracts for the management of plant disease increased in recent years and proved to be very effective against plant diseases.

In present investigation, the bio-control agents viz., Trichoderma-21, Trichoderma-28, Trichoderma-29, Trichoderma-72, Trichoderma-P, Pseudomonas fluoroscens and Bacillus subtilis were tested in vitro against Alternaria alternata. Trichoderma-21 was found most effective as compared to other bio control agents followed by Trichoderma-72, and produced maximum zone of inhibition. The least inhibition was recorded in Bacillus subtilis followed by Pseudomonas fluoroscens. The results are in accords with Strashnov et al., (1985) who reported effectiveness of Trichoderma harzianum against fruit rot of tomato caused by Alternaria alternata.

\section{Botanicals used for in vitro evaluation}

\begin{tabular}{|l|l|l|l|}
\hline Sl. No & Common name & Botanical name & Parts used \\
\hline 1 & Clerodendron & Clerodendron inermae & Leaves \\
\hline 2 & Garlic & Allium sativum & Cloves \\
\hline 3 & Kokum & Garcinia indica & Fruit \\
\hline 4 & Lantana & Lantana camera & Leaves \\
\hline 5 & Neem & Azadirachta indica & Kernel \\
\hline 6 & Onion & Allium cepa & Bulb \\
\hline 7 & Turmeric & Curcuma longa & Rhizome \\
\hline
\end{tabular}

Fungicides used in the in vitro study

\begin{tabular}{|c|c|c|c|}
\hline $\begin{array}{l}\text { Sl. } \\
\text { No. }\end{array}$ & Common name & Chemical name & Trade name \\
\hline \multicolumn{4}{|c|}{ Systemic fungicides } \\
\hline 1 & Carbendazim & Methyl 1-2-benzimidazole carbomate & Bavistin 50WP \\
\hline 2 & Difenconazole & Triazole & Score $25 \mathrm{EC}$ \\
\hline 3 & Hexaconazole & $\begin{array}{l}\text { RS)-2-(2,4-dichlorophenyl)-1-(1H- } \\
\text { 12,4-triazol-1-yl) hexan-2-ol }\end{array}$ & Contaf 5 EC \\
\hline 4 & Propiconazole & $\begin{array}{l}1-(2-(2,4 \quad \text { dichlorophenyl)-4-propyl- } \\
1,3 \text {-dioxolan-2yl }) \text { mythyl)-1H-1,2,4- } \\
\text { triazole }\end{array}$ & Tilt $25 \mathrm{EC}$ \\
\hline 5 . & Tebuconazole & $\begin{array}{l}\text { 1-(4-Chlorophenyl)-4,4-dimethyl-3- } \\
\text { (1H,1,2,4-triazol-1-ylmethyl)pentan- } \\
\text { 3-ol }\end{array}$ & Folicur $26 \mathrm{EC}$ \\
\hline \multicolumn{4}{|c|}{ Non-systemic fungicides } \\
\hline 1 & Captaf & $\begin{array}{l}\mathrm{N}(1,12,2, \text { tetrachloroenc- } 1-2- \\
\text { dicorboximide })\end{array}$ & Difoltan $25 \mathrm{WP}$ \\
\hline 2 & $\begin{array}{l}\text { Copper } \\
\text { oxychloride }\end{array}$ & Copper oxychloride & Blitox $50 \mathrm{WP}$ \\
\hline 3 & Chlorothalonil & 2,4,5,6-Tetrachloroisophthalonitrile & Kavach 75 WP \\
\hline
\end{tabular}


Table.1 In vitro evaluation of different systemic and non systemic fungicides against Alternaria alternate

\begin{tabular}{|c|c|c|c|c|c|c|}
\hline \multirow{3}{*}{ Sl. No. } & \multirow{3}{*}{ Fungicides } & \multicolumn{4}{|c|}{ Per cent inhibition over control } & \multirow{3}{*}{ Mean } \\
\hline & & \multicolumn{4}{|c|}{ Concentration } & \\
\hline & & $0.25(\%)$ & $0.5(\%)$ & $0.75(\%)$ & $1.0(\%)$ & \\
\hline 1 & Captaf (25 WP) & $\begin{array}{c}43.42 \\
(41.16) *\end{array}$ & $\begin{array}{c}57.56 \\
(49.41)\end{array}$ & $\begin{array}{c}63.76 \\
(52.93)\end{array}$ & $\begin{array}{c}79.00 \\
(62.93)\end{array}$ & $\begin{array}{c}60.91 \\
(51.56)\end{array}$ \\
\hline 2 & Carbendazim (50 WP) & $\begin{array}{c}78.33 \\
(62.26)\end{array}$ & $\begin{array}{c}84.00 \\
(66.42)\end{array}$ & $\begin{array}{c}86.00 \\
(68.32)\end{array}$ & $\begin{array}{c}93.00 \\
(74.68)\end{array}$ & $\begin{array}{c}85.41 \\
(67.92)\end{array}$ \\
\hline 3 & Chlorothalonil (75WP) & $\begin{array}{c}56.65 \\
(48.83) \\
\end{array}$ & $\begin{array}{c}67.34 \\
(55.14) \\
\end{array}$ & $\begin{array}{c}73.00 \\
(58.69) \\
\end{array}$ & $\begin{array}{c}83.00 \\
(65.65) \\
\end{array}$ & $\begin{array}{c}70.00 \\
(57.08) \\
\end{array}$ \\
\hline 4 & Copper oxychloride (75 WP) & $\begin{array}{c}57.00 \\
(52.14)\end{array}$ & $\begin{array}{c}62.33 \\
(58.48)\end{array}$ & $\begin{array}{c}72.67 \\
(49.02)\end{array}$ & $\begin{array}{c}82.33 \\
(65.16)\end{array}$ & $\begin{array}{c}68.58 \\
(56.20)\end{array}$ \\
\hline 5 & Difenconazole (25 EC) & $\begin{array}{l}100.00 \\
(89.71)\end{array}$ & $\begin{array}{l}100.00 \\
(89.71)\end{array}$ & $\begin{array}{l}100.00 \\
(89.71)\end{array}$ & $\begin{array}{l}100.00 \\
(89.71)\end{array}$ & $\begin{array}{l}100.00 \\
(89.71)\end{array}$ \\
\hline 6 & Hexaconazole (5 SC) & $\begin{array}{c}56.67 \\
(48.83)\end{array}$ & $\begin{array}{c}73.34 \\
(58.69)\end{array}$ & $\begin{array}{c}76.00 \\
(60.66)\end{array}$ & $\begin{array}{c}92.33 \\
(73.97)\end{array}$ & $\begin{array}{c}74.50 \\
(60.54)\end{array}$ \\
\hline 7 & Propiconazole (25 EC) & $\begin{array}{c}72.00 \\
(58.05) \\
\end{array}$ & $\begin{array}{c}93.21 \\
(74.68)\end{array}$ & $\begin{array}{l}100.00 \\
(89.71)\end{array}$ & $\begin{array}{r}100.00 \\
(89.71) \\
\end{array}$ & $\begin{array}{c}91.25 \\
(78.04) \\
\end{array}$ \\
\hline 8 & Tebuconazole (26 EC) & $\begin{array}{l}100.00 \\
(89.71)\end{array}$ & $\begin{array}{l}100.00 \\
(89.71)\end{array}$ & $\begin{array}{l}100.00 \\
(89.71)\end{array}$ & $\begin{array}{l}100.00 \\
(89.71)\end{array}$ & $\begin{array}{l}100.00 \\
(89.71)\end{array}$ \\
\hline \multirow{2}{*}{\multicolumn{2}{|c|}{ Mean }} & $\begin{array}{c}73.20 \\
(62.57) \\
\end{array}$ & $\begin{array}{c}81.33 \\
(68.03) \\
\end{array}$ & $\begin{array}{c}84.04 \\
(71.51)\end{array}$ & $\begin{array}{c}86.75 \\
(73.27)\end{array}$ & $\begin{array}{c}81.33 \\
(68.84)\end{array}$ \\
\hline & & \multicolumn{2}{|c|}{ Fungicides } & \multicolumn{2}{|c|}{ Concentration } & $\mathrm{F} \times \mathrm{C}$ \\
\hline & SEm \pm & \multicolumn{2}{|c|}{0.25} & \multicolumn{2}{|c|}{0.23} & 0.55 \\
\hline & CD@1\% & \multicolumn{2}{|c|}{0.88} & \multirow{2}{*}{\multicolumn{2}{|c|}{$\begin{array}{ll} & 0.62 \\
1.08 & \end{array}$}} & 1.77 \\
\hline & $\mathrm{CV}$ & & & & & \\
\hline
\end{tabular}

Table.2 In vitro evaluation of botanicals against Alternaria alternate

\begin{tabular}{|c|c|c|c|c|}
\hline \multirow{2}{*}{ Sl. No } & \multirow{2}{*}{ Common name } & \multicolumn{3}{|c|}{ Per cent inhibition } \\
\hline & & $5 \%$ & $10 \%$ & Mean \\
\hline 1 & Clerodendron leaf extract & $\begin{array}{c}50.36 \\
(45.21)^{*}\end{array}$ & $\begin{array}{c}61.10 \\
(51.41)\end{array}$ & $\begin{array}{c}55.73 \\
(48.31)\end{array}$ \\
\hline 2 & Drumstick leaf extract & $\begin{array}{c}42.96 \\
(40.95)\end{array}$ & $\begin{array}{c}50.73 \\
(45.42)\end{array}$ & $\begin{array}{c}46.84 \\
(43.18)\end{array}$ \\
\hline 3 & Garlic bulb extract & $\begin{array}{l}100.00 \\
(89.71)\end{array}$ & $\begin{array}{l}100.00 \\
(89.71)\end{array}$ & $\begin{array}{l}100.00 \\
(89.71)\end{array}$ \\
\hline 4 & Kokum fruit extract & $\begin{array}{c}50.36 \\
(45.20)\end{array}$ & $\begin{array}{c}52.59 \\
(46.48)\end{array}$ & $\begin{array}{c}51.47 \\
(45.84)\end{array}$ \\
\hline 5 & Lantana leaf extract & $\begin{array}{c}48.14 \\
(43.93)\end{array}$ & $\begin{array}{c}60.36 \\
(50.98)\end{array}$ & $\begin{array}{c}54.25 \\
(47.45)\end{array}$ \\
\hline 6 & Neem seed kernel extract & $\begin{array}{c}38.14 \\
(38.13)\end{array}$ & $\begin{array}{c}75.18 \\
(60.14)\end{array}$ & $\begin{array}{c}56.66 \\
(49.13)\end{array}$ \\
\hline 7 & Onion bulb extract & $\begin{array}{l}100.00 \\
(89.71)\end{array}$ & $\begin{array}{l}100.00 \\
(89.71)\end{array}$ & $\begin{array}{l}100.00 \\
(89.71)\end{array}$ \\
\hline 8 & Turmeric rhizome extract & $\begin{array}{c}48.14 \\
(43.93)\end{array}$ & $\begin{array}{c}61.62 \\
(51.72)\end{array}$ & $\begin{array}{c}54.88 \\
(47.82)\end{array}$ \\
\hline \multirow{3}{*}{\multicolumn{2}{|c|}{$\begin{array}{c}\mathrm{SEm} \pm \\
\mathrm{CD} @ 1 \% \\
\mathrm{CV}\end{array}$}} & 1.08 & 1.04 & 1.06 \\
\hline & & 3.29 & 3.16 & 3.25 \\
\hline & & 3.1 & 2.59 & 2.85 \\
\hline
\end{tabular}


Table.3 In vitro evaluation of bio-agents against Alternaria alternate

\begin{tabular}{|c|c|c|}
\hline Sl. No & Bio-agents & Percent inhibition of mycelial growth \\
\hline 1 & Trichoderma-21 & $\begin{array}{c}83.00 \\
(65.65)^{*}\end{array}$ \\
\hline 2 & Trichoderma -28 & $\begin{array}{c}80.00 \\
(63.43)\end{array}$ \\
\hline 3 & Trichoderma -29 & $\begin{array}{c}81.33 \\
(64.40)\end{array}$ \\
\hline 4 & Trichoderma -72 & $\begin{array}{c}87.00 \\
(68.87)\end{array}$ \\
\hline 5 & Trichoderma $-\mathrm{P}$ & $\begin{array}{c}61.00 \\
(51.35)\end{array}$ \\
\hline 6 & $\begin{array}{l}\text { Pseudomonas } \\
\text { fluorescens }\end{array}$ & $\begin{array}{c}12.00 \\
(20.25)\end{array}$ \\
\hline 7 & Bacillus subtilis & $\begin{array}{c}7.66 \\
(16.02)\end{array}$ \\
\hline \multirow{3}{*}{\multicolumn{2}{|c|}{$\begin{array}{c}\text { SEm } \pm \\
\text { CD@ } 1 \% \\
\text { CV }\end{array}$}} & 0.52 \\
\hline & & 1.55 \\
\hline & & 1.61 \\
\hline
\end{tabular}

* Figures presented in parantheses are angular transformed values.

Fig.1 In vitro evaluation of different fungicides against Alternaria alternate

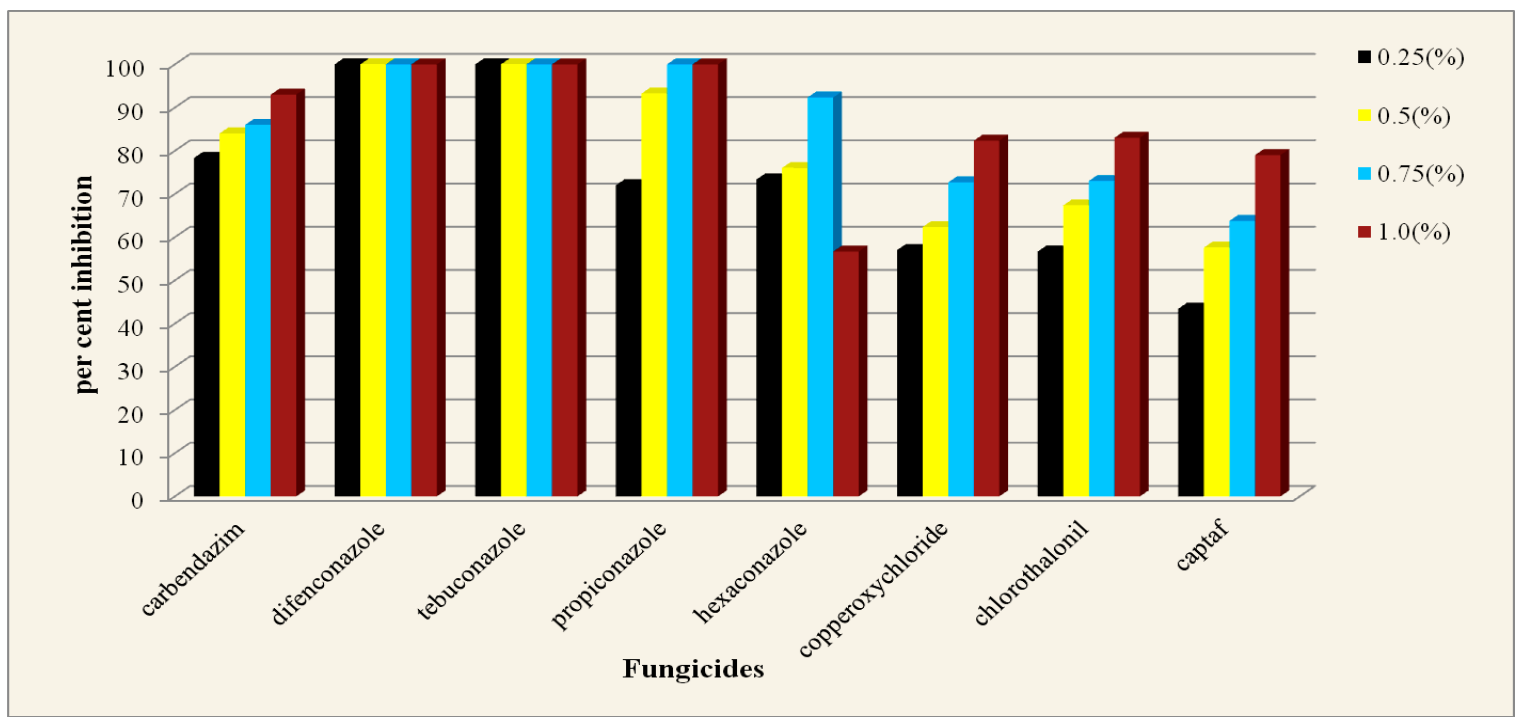


Fig.2 Evaluation of different plant extracts on the growth of Alternaria alternata under in vitro condition

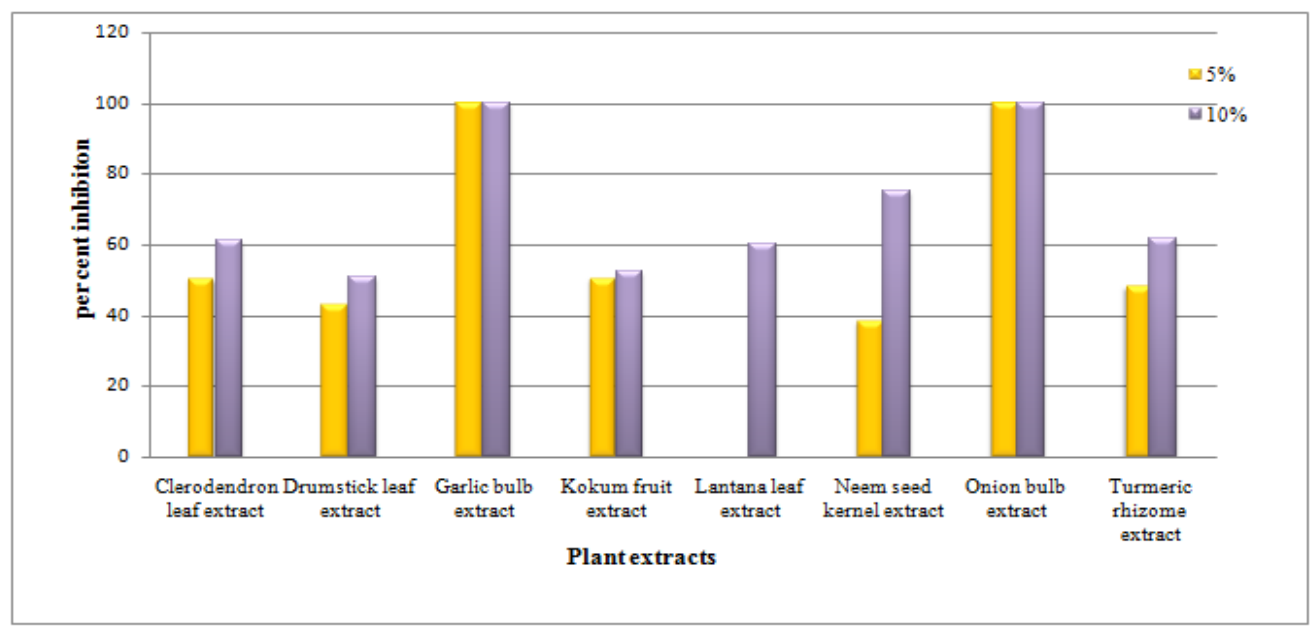

Fig.3 Evaluation of different bio-agents against Alternaria alternata under in vitro conditions

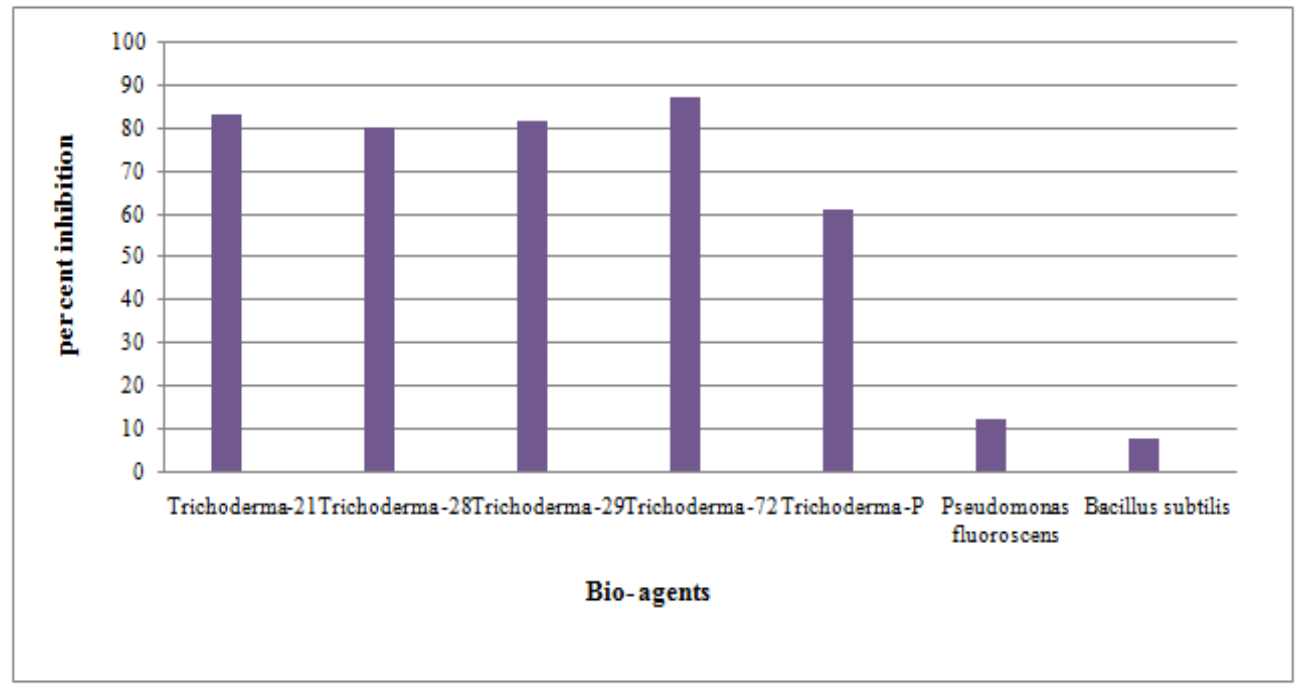

However Babu et al., (2000) reported that Trichoderma harzianum and Trichoderma viride were significantly superior in inhibiting the mycelial growth of Alternaria solani, causing leaf blight of tomato. However the findings of our investigation in contrary with Vadilal and Ebenezer (2006) reported that maximum inhibition of mycelial growth and sporulation of Alternaria solani with biocontrol agents of Bacillus subtilis, Trichoderma viride and Gliocladium virens.
The antagonism of Trichoderma spp. against many fungi is mainly due to production of acetaldehyde compound (Robinson and Park, 1966 and Dennis and Webster, 1971). Though, the genus Trichoderma comprises a large number of species some of which act as biological control agents through one or more mechanisms. Sharma et al., 2012 reported that Trichoderma strains exert control against fungal phytopathogens either indirectly by competing for nutrients and space, modifying 
the environmental condition, promoting plant growth, plant defensive mechanisms and antibiosis, or directly by mechanisms such as mycoparasitism. Activation of each mechanism implies the production of specific metabolites, such as plant growth factors, hydrolytic enzymes, siderophores, antibiotics, and permeases. Specific strains of fungi in the genus Trichoderma colonize and penetrate plant root tissues and initiate a series of morphological and biochemical changes in the plant, considered to be part of the plant defense response, which subsequently leads to induced systemic resistance. Antibiosis occurs during interactions with other microorganisms involving low molecular weight diffusible volatile and nonvolatile toxic metabolite compounds or antibiotics like harzianic acid, alamethicins, tricholin, eptaibols, antibiotics, 6-penthylpyrone, in consideration of all these factors involving in suppression of pathogen growth results Trichoderma is an effective bio control agent. In order to tackle these global problems, effective alternatives to chemical control are being investigated and the use of antagonistic microbes as biocontrol agent seems to be one of the promising approaches. With the advent of biocontrol as a potential approach to Integrated Pest Management (IPM) in the area of fungi-mediated plant disease control, the genus Trichoderma has gained considerable importance.

\section{References}

Anonymous. 2014. Indian Horticulture database, $N H B$, pp. 131-132.

Babu, S., Seetharman, K., Nandakumar, R. and Johnson, I. 2000. Variability in cultural characteristics of tomato leaf blight pathogen. Pl. Dis. Res., 15: 121.

Begum, F. and Bhuiyan, M.K.A. 2006. Integrated control of seedling mortality of lentil caused by Sclerotium rolfsii. Bangladesh J. Pl. Path., 23: 60-65.

Bollen, G.J. and Fuchs, A. 1970. On the specificity of the in vitro and in vivo antifungal activity of benomyl. Netherlands J. Pl. Patho., 76: 299-312.

Chaudhary, R.F., Patel, R.L., Chaudhari, S.M., Pandey, S.K. and Singh, B. 2003. In vitro evaluation of different plant extracts against Alternaria alternata causing early blight of potato. J. Indian Potato. Asso., 30: 141-142.

Dennis, C. and Webster, J. 1971. Antagonistic properties of species groups of Trichoderma Production of volatile antibiotics. Trans. British Mycol. Soci., 57: 41-48.

Edgington, L.V., Khew, K.L., Barron, G.L. 1970. Fungitoxic spectrum of benzimidazole com- pounds. Phytopath., 61: 42-46.

Ghosh, C., Pawar, N.B., Kshirsagar, C.R. and Jadhav, A.C. 2002. Studies on management of leaf spot caused by Alternaria alternata on gerbera. $J$. Maharastra Agric. Uni., 27:165-167.

Harish, D.K., Agasimani, A.K., Imamsaheb, S.J. and Patil Satish, S. 2011. Growth and yield parameters in brinjal as influenced by organic nutrient management and plant protection condition. J. Agric. Sci., 2(2): 221-225.

Kalra, J.S. and Sohi, H.S. 1984 Studies on post harvest rots of tomato fruits. Control of Alternaria fruits rot. Indian J. Mycol. Pl. Path., 15(3): 256-261.

Kamble, P., U. Ramiah, M. and Patil, D.V. 2000. Efficacy of fungicides in controlling leaf spot disease of tomato caused by Alternaria alternata (Fr.) Kessiler. J. Soil Sci. Crops, 10: 36-38.

Mathur, K. and Shekhawat, K.S. 1986. Chemical control of early blight in Kharif sown tomato. Indian J. Mycol. Pl. Path.., 16: 235-236.

Nene, Y.L. and Thapliyal, P.N. 1982. Fungicides in Plant Diseases control. Oxford and IBH Publishing Co. Pvt. Ltd., New Delhi, p. 163. 
Nene, Y.L. and Thapliyal, P.N. 1973. Fungicide in Plant Diseases control, III edition. Oxford and IBH Publishing Co. Pvt. Ltd., New Delhi, p. 325. Edgington, L. V., Khew, K. L., Barron, G. L., 1970, Fungitoxic spectrum of benzimidazole com- pounds. Phytopath., 61: 42-46.

Panchal, D.G. and Patil, R.K. 2009. Ecofriendly management of fruit rot of tomato caused by Alternaria alternata. J. Mycol. Pl. Path., 39(1): 66-69.

Prasad, Y. and Naik, M.K. 2003. Evaluation of genotype fungicides and plant extracts against early blight of tomato caused by Alternaria solani. Indian J. Pl. Pro., 30(2): 49-53.

Robinson, P.M. and Park, D. 1966. Volatile inhibitor of spore germination produced by Taagi. Trans. British Mycol. Soc., 49: 639-649.

Sharma, M., Razdan, V.K. and Rajik, M. 2012. In vitro evaluation of fungicides and biocontrol agents against brinjal leaf blight and fruit rot pathogen Phomopsis vexans (sacc. \& syd.) Harter. Bioinfolet., 9(3): 327 - 332.

Singh, J. and Majumdar, V.L. 2001. Efficacy of plant extract against Alternaria alternata. The incitant of fruit rot of pomegranate (Punica granatum L). J. Mycol. Pl. Path., 31(3): 346-349.

Singh, M. and Shukla, T.N. 1984. Chemical control of Alternaria leaf spot and fruit rot of brinjal caused by Alternaria alternata. Indian J. Mycol. $\mathrm{Pl}$. Phytopath., 14(1): 81-83.

Smith, B.J. and Black, L.L. 1990. Morphological, Cultural and Pathogenic variation among Colletotrichum sp. from Strawberry. Pl. Dis., 74: 69-76.

Snel, M., Schmeling, V.B. and Edgington, L.V. 1970. Fungitoxicity and structureactivity relationships of some oxathiin and thiazole derivatives. Phytopatho. 60: 1164-1169.

Strashnov, Y., Elad, Y., Sivan, A., Rudich, Y. and Chot, I. 1985. Control of Rhizoctonia solani fruit rot of tomatoes by Trichoderma harzianum Rifai. Crop Protection, 4: 359-364.

Vincent, J.M. 1927. Nature, 159 p: 850.

Vadilal, S. and Ebenezar, E.G. 2006. Ecofriendly management of leaf blight of tomato caused by Alternaria alternata. J. Mycol. Pl. Pathol., 36(1): 79-83.

\section{How to cite this article:}

Sanjeev P. Jakatimath, R.K. Mesta, I.B. Biradar, Sadanand K. Mushrif and Ajjappalavar, P.S. 2017. In vitro Evaluation of Fungicides, Botanicles and Bio-Agents against Alternaria alternata Causal Agent of Fruit Rot of Brinjal. Int.J.Curr.Microbiol.App.Sci. 6(5): 495-504. doi: https://doi.org/10.20546/ijcmas.2017.605.058 